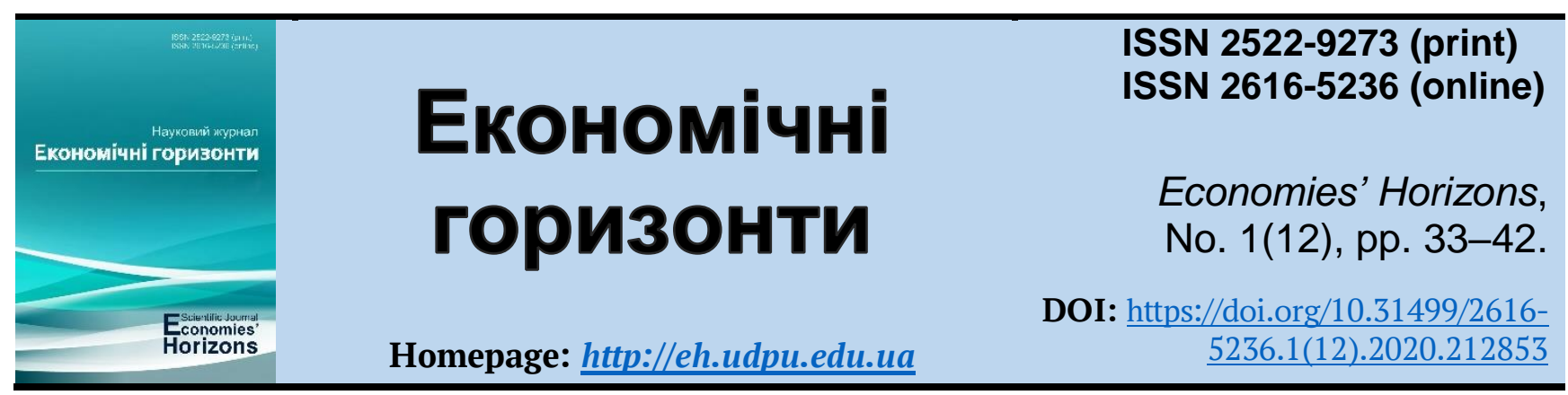

UDC 331.101.3

\title{
System arrangement of labor motivation and methodological approaches to the comprehensive assessment during the stage of innovative changes
}

Oleksandr P. Kirdan ${ }^{1}$, Cand. Ec. Sc., Associate Professor

Olena A. Harnyk ${ }^{2}$, Cand. Ec. Sc., Associate Professor

Anatolii L. Berzhanir ${ }^{3}$, Cand. Soc. Sc., Associate Professor

Received: 2 February 2020

Accepted: 5 March 2020
Kirdan, O. P., Harnyk, O. A. and Berzhanir, A. L. (2020), "System arrangement of labor motivation and methodological approaches to the comprehensive assessment during the stage of innovative changes", Economies' Horizons, no. 1(12), pp. 33-42. doi: https://doi.org/10.31499/2616-5236.1(12).2020.212853

Abstract. Purpose of the research. The purpose of the article is to substantiate the basic theoretical provisions of the formation of labor motivation and methodological approaches to its complex assessment at the stage of innovative changes in the economy. Methodology. In the course of the research general theoretical methods were used: dialectical for knowledge of economic processes; systematic and institutional approaches for the implementation of theoretical generalizations and conclusions in determining the components of the system of labor motivation and factors of its development, to assess the experience of developed countries in the construction of a system of labor motivation in the conditions of an innovative model of the economy. Results. The essence and peculiarities of formation of the mechanism of labor motivation in the conditions of innovative development are investigated in the article. The system of methods, which application will increase the level of motivation of employees, is distinguished. The necessity of objective evaluation of the effectiveness of methods of work motivation and the system of work motivation using quantitative and qualitative indicators is proved. Practical meaning. The proposed methodology of comprehensive evaluation of the system of labor motivation can be used in the formation and improvement of the system of labor motivation, taking into account the peculiarities of innovative development of the economy and the innovative direction of the activities of economic entities. Prospects for further research. The prospect of further research should be to improve the socio-economic mechanism of labor motivation in the conditions of formation of an innovative model of economy.

Keywords: labor motivation, innovative development, innovative approach to the labor motivation formation, labor motivation methods, evaluation of the effectiveness of labor motivation methods.

JEL Classification: J24, M21, O33.

\footnotetext{
${ }^{1}$ Pavlo Tychyna Uman State Pedagogical University; Head of the Department of Economy and Socio-Behavioral Sciences; ORCID ID: https://orcid.org/0000-0003-2667-6589; e-mail: kirdan alex@ukr.net.

${ }^{2}$ Pavlo Tychyna Uman State Pedagogical University; Associate Professor at the Department of Economy and Socio-Behavioral Sciences; ORCID ID: https://orcid.org/0000-0003-1079-2569; e-mail: garnuk elena@ukr.net. ${ }^{3}$ Pavlo Tychyna Uman State Pedagogical University; Associate Professor at the Department of Economy and Socio-Behavioral Sciences; ORCID ID: https://orcid.org/0000-0002-3224-5008; e-mail: bal8@ukr.net.
} 
Number of references: 17; number of tables: 1; number of figures: 2; number of formulas: $\mathbf{0}$.

\title{
Формування системи мотивації праці та методичні підходи щодо її комплексної оцінки на етапі інноваційних змін
}

\author{
Олександр Петрович Кірдан ${ }^{1}$, к. е. н., доцент \\ Олена Анатоліївна Гарник ${ }^{2}$, к. е. н., доцент \\ Анатолій Леонідович Бержанір ${ }^{3}$, к. соц. н., доцент
}

Стаття надійшла: 02.02.2020

Стаття прийнята: 05.03.2020
Kirdan O. P., Harnyk O. A., Berzhanir A. L. System arrangement of labor motivation and methodological approaches to the comprehensive assessment during the stage of innovative changes. Економічні горизонти. 2020. № 1(12). C. 33-42 DOI: $\underline{10.31499 / 2616-5236.1(12) .2020 .212853 ~}$

Анотація. Мета дослідження. Метою статті є обгрунтування основних теоретичних положень формування мотивації праці та методичних підходів щодо її комплексної оцінки на етапі інноваційних змін в економіці. Методологія. У процесі виконання дослідження використано загальнонаукові теоретичні методи: діалектичний - для пізнання економічних процесів; системний та інституційний підходи - для здійснення теоретичних узагальнень та висновків під час визначення складових системи мотивації праці та чинників іiі розвитку, для здійснення оцінки досвіду розвинених країн світу щодо побудови системи мотивації праці в умовах інноваційної моделі економіки. Результати. У статті досліджено сутність та особливості формування механізму мотивації праці в умовах інноваційного розвитку. Виокремлено систему методів, застосування яких впливатиме на підвищення рівня вмотивованості працівників. Доведено необхідність об’єктивної оцінки результативності методів мотивації праці та системи мотивації праці за допомогою кількісних і якісних показників. Практичне значення. Запропонована методика комплексної оцінки системи мотивації праці може буде використана під час формування та вдосконалення системи мотивації праці, з урахуванням особливостей інноваційного розвитку економіки та інноваційного спрямування діяльності суб’єктів господарювання. Перспективи подальших досліджень. Перспективи подальших досліджень. Перспективою подальших досліджень має стати удосконалення соціально-економічного механізму мотивації праці в умовах становлення інноваційної моделі економіки.

Ключові слова: мотивація праці, інноваційний розвиток, інноваційний підхід до формування мотивації праці, методи мотивації праці, оцінка ефективності методів мотивації праці.

Кількість джерел: 17; кількість таблиць: 1; кількість рисунків: 2; кількість формул: 0.

\section{Introduction.}

In our modern society, any change is a necessary factor in the socio-economic system. Changes occur in every system of socio-economic development and, accordingly, bring about shifts that build a competitive environment. It is innovative changes that determine the cyclical nature of socio-economic evolution. Therefore, the evolutionary process in the economic system occurs through the

\footnotetext{
${ }^{1}$ Уманський державний педагогічний університет імені Павла Тичини; завідувач кафедри економіки та соціально-поведінкових наук; ідентифікатор ORCID: https://orcid.org/0000-0003-2667-6589; e-mail: kirdanalex@ukr.net.

${ }^{2}$ Уманський державний педагогічний університет імені Павла Тичини; доцент кафедри економіки та соціально-поведінкових наук; ідентифікатор ORCID: https://orcid.org/0000-0003-1079-2569; e-mail: garnukelena@ukr.net.

3 Уманський державний педагогічний університет імені Павла Тичини; доцент кафедри економіки та соціально-поведінкових наук; ідентифікатор ORCID: https://orcid.org/0000-0002-3224-5008; e-mail: bal8@ukr.net.
} 
innovation process. Technological innovations stimulate the modernization and technical restructuring of society. Innovators represent the mechanism of ways of development of socioeconomic system.

A necessary condition and objective need for innovative changes is, first and foremost, the activation of the human factor, which is achieved through the formation of a new progressive system of work motivation, which is based on the integrated use of social-psychological, economic, organizational-administrative, technological and innovative methods of motivation . In the conditions of increasing intellectualization and innovativeness of work, methodological approaches to the complex evaluation of the system of motivation of work are improved, which allows to evaluate modern tendencies and peculiarities of its formation at macro-, meso-, microeconomic levels and influence on social and labor relations in conditions of innovative economic development.

\section{Literature review.}

The basis of modern scientific ideas about work motivation and its components are laid by the works of world-renowned scientists, such as: A. Maslow (1943), E. Mayo (1946), F. Taylor (1947), D. McGregor (1960), J. Adams (1963), F. Herzberg (1966), V. Vroom and A. Jago (1988), D. McClelland (1987) and others. Significant contribution to the study of problems of formation of new (innovative) labor motivation and evaluation of the effectiveness of methods of motivation of work were the scientific works of Ukrainian researchers, in particular: L. Koval (2002), M. Semykina and L. Koval (2002), O. Hrishnova (2004), D. Bohynia (2008), A. Kolot (2008), M. Semykina (ed.) et al. (2012) and others.

\section{Methods.}

The theoretical and methodological basis of the study is the dialectical methods of cognition of economic processes, systemic and institutional approaches, which provide for the study of phenomena in their constant development and interconnection and to ensure conceptual unity of research. For the theoretical substantiation of the essence of the concept of "system of labor motivation" were used methods of logical generalization and analogy, and in determining the components of the system of labor motivation and factors of its development in the conditions of innovative model of economy methods of system analysis, classification, comparison.

\section{Research objectives.}

Increasing competitiveness on the basis of mastering the innovative model of development requires progressive shifts in the development of productive forces of society, which is impossible without radical changes in the paradigm of work motivation, because the existing system of motivation remains ineffective, contrary to the goals of innovative development, increasing the competitiveness of enterprises. Therefore, in the conditions of innovative development of the economy, there is a need to deepen scientific research in the direction of substantiation of new factors, mechanisms and peculiarities of labor motivation and to improve methodological approaches to a comprehensive assessment of its system of functioning, which are based on the isolation of methods of labor motivation and relevant groups of its indicators.

In the modern scientific literature, the issue of work motivation has been considered quite broadly, but the problem of forming a new (innovative) work motivation and evaluating the effectiveness of its functioning can not be fully resolved. Therefore, there is a need to identify the peculiarities of the formation of labor motivation in the conditions of innovative development of the economy and to improve methodological approaches for evaluating its effectiveness at the stage of innovative changes, which leads to effective work, implementation of scientific and technological progress, the development of creative activity of workers to meet the individual and society needs. 


\section{Results and discussions.}

In the process of innovative changes that are taking place in Ukrainian society, a necessary objective need is the formation of a new system of work motivation. The implementation of an innovative model of development requires the creation at the state level of appropriate systemic conditions for progressive motivation and stimulation of labor activity of the population.

The process of forming a new (innovative) work motivation cannot be subordinated to the general scheme of labor motivation, but must have its specific features. After all, the motivation of work in the conditions of innovative changes, which are based on the flow of innovations, technological improvement, production and export of high-tech products, on intellectualization, implies increasing demands on employees: for meaningful work; manifestation of independence; aspiration for creative self-realization; initiative; striving for knowledge and creation of new (purely cognitive and creative needs) (Semykina and Koval, 2002).

The motivation of work in the conditions of innovative development is based on the necessity of rationalization of production, servicing, management processes on the basis of improvement of functional and production structures, increase of efficiency of use of personnel, information, financial, material resources, restoration of production-technical and engineering base.

Synthesizing various approaches to the interpretation of work motivation in terms of innovative development, it can be argued that its content corresponds to the general patterns of «work motivation» and has its specific features. In this regard, it is advisable to identify and compare two approaches to the formation of work motivation: the traditional approach used in the era of industrial economy; an innovative approach focused on the formation of work motivation in the conditions of innovative development (Table 1).

\section{Table 1. Comparative characteristics of traditional and innovative approaches to the} formation of labor motivation

\begin{tabular}{|c|c|c|}
\hline Criteria & Traditional approach & Innovative approach \\
\hline The salary level & $\begin{array}{l}\text { Salary itself is a strong motivator. Salary in- } \\
\text { crease occurs in connection with the general or- } \\
\text { ganizational development and not depending on } \\
\text { those results which are reached by a particular } \\
\text { worker. At the same time there are no signifi- } \\
\text { cant differences in salary between effective and } \\
\text { ineffective employees. }\end{array}$ & $\begin{array}{l}\text { Work done well is adequately regarded there by im- } \\
\text { proving the efficiency of other tasks. Workers mak- } \\
\text { ing the largest contribution to the strategic goals of } \\
\text { the organization deserve the greatest reward. Salary } \\
\text { increase is carried out not by "equalizing" and var- } \\
\text { ies depending on the results which are reached by a } \\
\text { particular employee. }\end{array}$ \\
\hline $\begin{array}{l}\text { Results of the } \\
\text { company }\end{array}$ & $\begin{array}{l}\text { They are the simple sum of results of each of } \\
\text { the employees. That is, if each of the employees } \\
\text { reaches the individual (usually quantitative) ob- } \\
\text { jectives, goals of the company will be automati- } \\
\text { cally achieved. }\end{array}$ & $\begin{array}{l}\text { They are directly dependent on the interaction be- } \\
\text { tween employees, team work and not only on the } \\
\text { individual achievement. }\end{array}$ \\
\hline $\begin{array}{l}\text { Delegation of } \\
\text { authority }\end{array}$ & $\begin{array}{l}\text { It involves a partial or complete waiver of such } \\
\text { technology as delegation of authority. }\end{array}$ & $\begin{array}{l}\text { Delegation of authority frees the head from opera- } \\
\text { tional management process, increases the motiva- } \\
\text { tion of employees, raises the level of efficiency of } \\
\text { the company response to external factors and pro- } \\
\text { vides more freedom in achieving organizational } \\
\text { goals. }\end{array}$ \\
\hline $\begin{array}{l}\text { Career } \\
\text { management }\end{array}$ & $\begin{array}{l}\text { It involves promoting an employee up through } \\
\text { the ranks of the company ("vertical career"). }\end{array}$ & $\begin{array}{l}\text { It involves the promotion of employees within the } \\
\text { organization not only up through the ranks but also } \\
\text { from one unit to another company ("horizontal" or } \\
\text { "matrix" career). }\end{array}$ \\
\hline $\begin{array}{l}\text { Corporate } \\
\text { culture }\end{array}$ & $\begin{array}{l}\text { It is implemented on the basis of traditions } \\
\text { formed in many enterprises. This approach does } \\
\text { not imply the need to deal specifically with the } \\
\text { formation and management of corporate culture } \\
\text { as a whole. }\end{array}$ & $\begin{array}{l}\text { It implies purpose full formation of ideas, opinions } \\
\text { and fundamental values shared by members. Also, } \\
\text { values define styles of behavior, styles of communi- } \\
\text { cation with colleagues and clients, the level of mo- } \\
\text { tivation, activity and others. }\end{array}$ \\
\hline
\end{tabular}

Source: compiled by the authors. 
In a general sense, work motivation in the context of innovative development is a process of encouragement aimed at creating new things in science, economics, the arts (as well as in any other sphere). In this regard, the work of staff in an innovative environment, characteristic of modern business conditions, can be considered as a combination of a regulated and innovative component.

With the acquisition of innovative, intellectual character in the motivational sphere of personality, the need for self-fulfillment and the desire to reveal one's personality comes to the fore. People are interested not only in encouraging the initiation and introduction of innovations or material rewards that carry the success of an idea, but to a large extent the content of the activity itself. Such a situation, when the desire for self-realization, creative achievements comes from the employee himself, and not from the "external factor» is determined by the most effective method of raising labor in the conditions of innovative changes of the economy (Semykina (ed.) et al., 2012).

Regardless of how work motivation is considered in terms of innovative development, most researchers (Bohynia, 2008; Kolot, 2008; Koval, 2002; Bakulina, 2015) emphasize its features: intelligence, professionalism, innovative character, activity, creativity, creativity, initiative, self-development, and also that it needs more freedom of the employee both in the performance of their work tasks and in the management of their own actions. All this requires the development of the individual, the enrichment of its value-motivational sphere and specific methods of managing it.

Based on the above, the essence of the concept of work motivation in terms of innovative economic development, in our opinion, is the process of interaction of objective and subjective factors and the use of innovative (non-traditional) methods of influence, which encourage the activity of creative content aimed at creating innovative products, ser- vices, organizational forms of their use, introduction of new technologies and innovations to ensure the quality of workforce, competitiveness of labor.

Methods of work motivation - a set of techniques and methods of encouraging employees to achieve the goals of the organization on the basis of reconciliation of their goals and objectives of the organization through continuous research and activation of the structure of work motives. These methods, based on the laws and laws of management, involve the use of various techniques of influence on staff to enhance its activities.

On the basis of generalizations of different scientific approaches, we propose to distinguish five main groups of methods of work motivation - social-psychological, economic, organizational-administrative, technical-technological, innovative methods. All these motivation methods are interrelated.

Recently, along with such common standard methods of motivation as wages, bonuses, gratitude, innovative, so to speak, nonstandard methods of motivation are emerging. Non-standard types of work motivation include such as: positive psychological climate in the company; favorable physical working conditions (e.g. cleanliness in the office, comfortable workplace, modern equipment, etc.); convenient location of the office; paid lunches; shorter working day; providing opportunities to study and improve their skills, internal corporate trainings; career opportunities in the company; availability of a career plan for employees; greetings from the company: official holidays, birthdays; regular competitions for the best employee, etc.

Therefore, it is important to understand that during the formation of work motivation in the conditions of innovative development it is necessary to use and introduce stable and timely material incentives; promotion of improvement of skill, qualification of employees; consideration of individual features of work motivation; empowerment and professional- 
ism; independence and autonomy of employees; respect for the individual, stimulation to search for new, promising ideas for improvement of activity and material (moral) encouragement of creativity in the workplace.

The basis for building a system of work motivation is formed at three levels: at the enterprise or organization level, at the regional level and at the state level. The basic principles of construction of this system are, on the one hand, the formation of higher-level needs of employees for the formation of factors of intrinsic motivation (human needs, interests, values, national mentality, initiative, professional skill), and on the other - creating favorable conditions for achievement goals of the organization as a whole by identifying and meeting the needs of employees (internal factors - organizational-economic, social-psychological, intellectual (educational-cultural) and innovative).
The compliance with the above requirements of building a system of motivation of work, encourages employees to be active in order to achieve this goal and allows to ensure a dynamic balance between the results of work and remuneration, between the needs of different groups of stakeholders in the enterprise.

Summarizing the above, we have reason to argue that the system of motivation of work in the conditions of innovative changes in the economy is characterized by the most complete form of organization of motivation, which is a set of elements whose role is played by motivation methods and interacting internal factors (at the level of the individual), which are formed under influence of external factors acting at the micro, meso-, macroeconomic levels and stimulate the activation of creative content and aimed at creating innovative products, services, body insulation forms of their implementation and use (Figure 1).

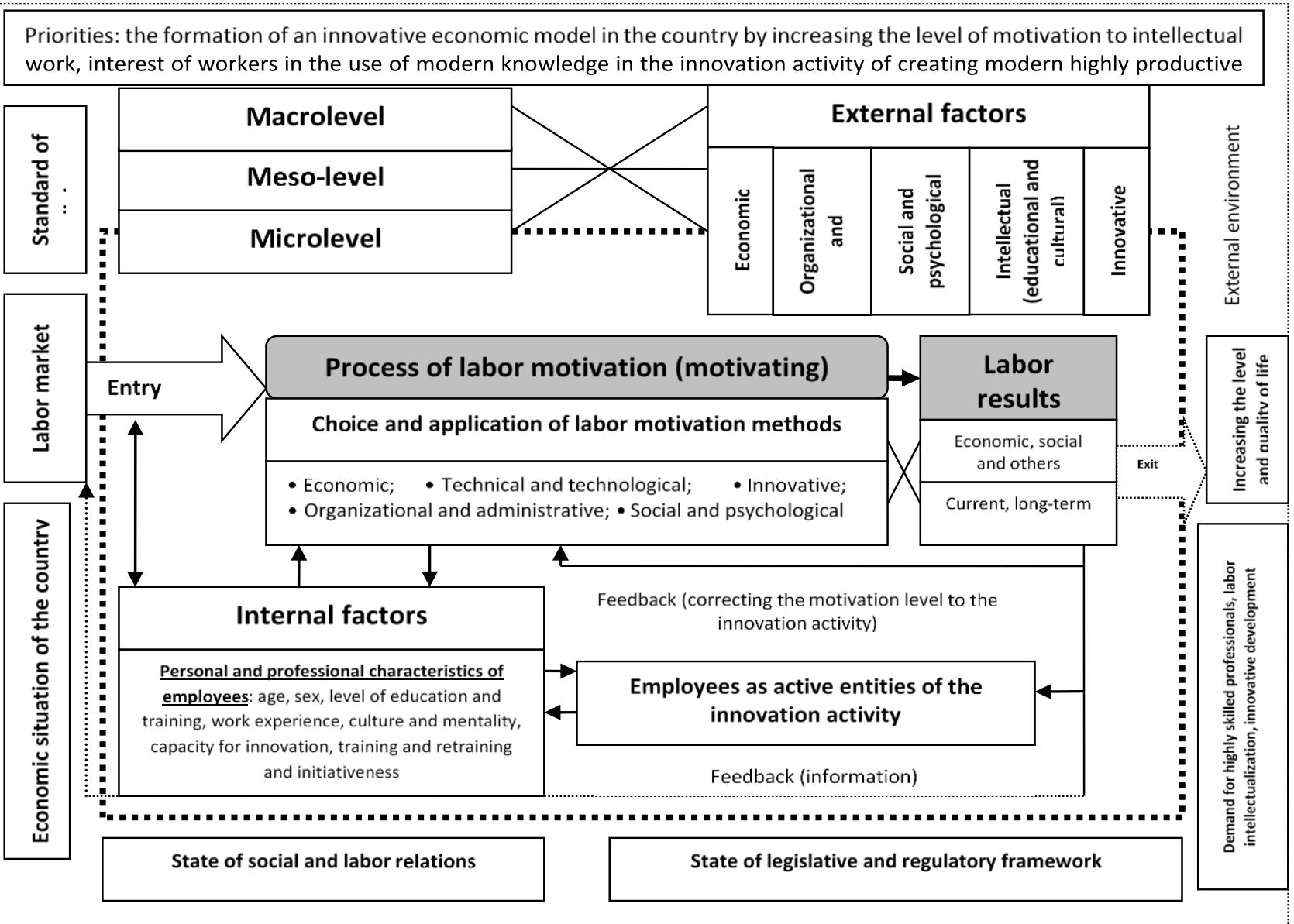

Fig. 1. Conceptual diagram of labor motivation in terms of the innovative economic development

Source: developed by the authors. 
In order to determine the effectiveness of the system of labor motivation in the conditions of innovative changes in the economy, it is necessary to carry out its evaluation and to define a system of indicators. Assessment of work motivation is to determine the extent to which each employee achieves the expected results of work and meets those requirements that come from his production tasks (Figure 2).

A meaningful assessment of work motivation is possible provided appropriate methods are used. In modern scientific literature, a considerable number of methods are proposed: methods of statistical analysis; sociological methods (surveys, experiments, observations, sociographic method); economic and mathematical methods; classification and analytical methods; graphical-analytical, etc. These methods provide information about the level of achievement of the goals of the enterprise and employees (Kolot, 2008).

There are two types of methods of evaluation of work motivation: self-assessment and complex (external) assessment. Allocate in the model of forming a system of integrated work motivation to achieve the final results of activity (as an object of quantitative and qualitative assessments of staff): professional qualities and activity of the employee; activity of the head; the activities of the team; interconnections (consumers, employees, executives) motivation of behavior (Ageev, 1984). Self-esteem is carried out by the worker himself on the basis of his own idea of life goals, work activity, his values for the enterprise.

The content of the evaluation of work motivation consists in the assessment of the personal qualities of employees (object, criteria), the evaluation of work (measuring and estimating labor costs over time, assessing the complexity of work and content of work) and the evaluation of work results (direct results, side results). However, in order for the system of evaluation of work motivation at the enterprise to be effective, during its implementation it is necessary to carry out an assessment of employees' business qualities, complexity of their functions and results of work, etc.

Staff evaluation has two functions: an orientation, which is that each employee, through self-assessment and evaluation by the team, managers, consumers, etc., is aware of his / her status and behavior and is able to determine the directions and ways of further activity. The incentive function is that it generates in the employee experiences of success or failure, confirming the correctness or falsity of behavior, encourages him to act in the right direction.

The process of managing the motivation of work at the enterprise should be carried out on the basis of a set of indicators that qualitatively and quantitatively reflect its level. The indicator refers to the qualitative and quantitative assessment of the processes and phenomena of the environment. The qualitative side of the indicator reflects the content of phenomena or processes in specific conditions of place and time, quantitative - the size, absolute and relative value. Thus, an indicator is a qualitative and quantitative characteristic of an object, expressed by a number that indicates its properties.

However, there are some problems associated with measuring work motivation: the need to use different indicators; the presence of a large number of factors that influence work motivation with varying strengths and sometimes in opposite directions; the variety of forms and ways of manifesting work motivation, both objective and subjective; the difficulty of drawing a line between work motivation as a socio-economic and socio-psychological category. It should be emphasized that the motivation of the work of a particular collective, social group, subjects and objects of management is expressed in two forms: in thoughts and judgments (the so-called verbal motivation of work) and in the real behavior of people. Accordingly, there are two types of indicators of evaluation of work motivation: subjective and objective (Shershniova, Bahatskyi and Hetmantseva, 2007). 


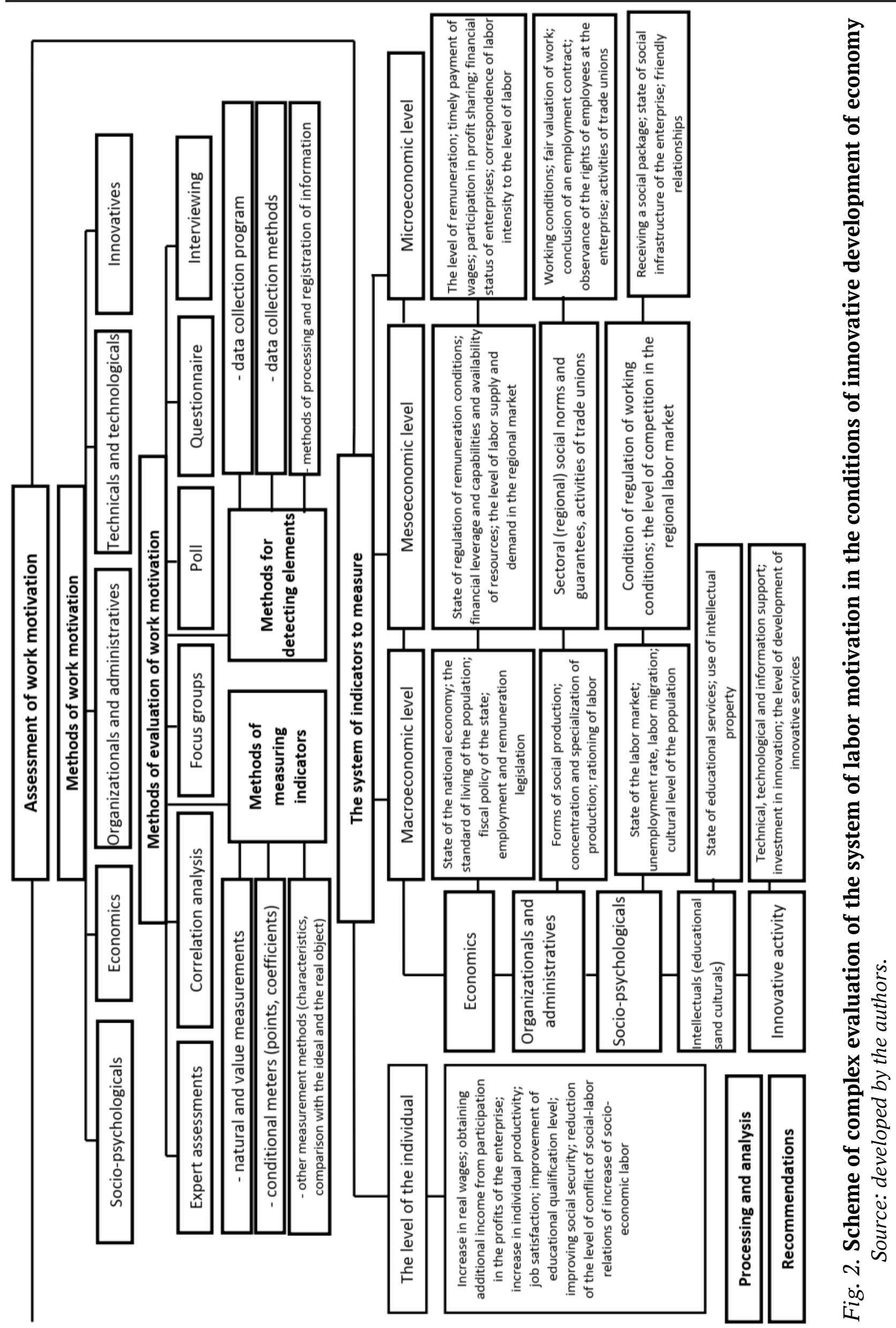


Objective quantitative and qualitative indicators are required to evaluate the effectiveness of work motivation methods and work motivation systems at the micro, meso- and macroeconomic levels. Quantitative metrics represent the absolute dimensions associated with measuring the size of a set of objects (elements). The baseline for obtaining quantitative indicators is regulatory, planning, accounting, and analytical information.

Qualitative indicators determine the level of development of the process, qualitative features of the phenomena, patterns of their development (the degree of use of social work, production resources, productivity growth, profitability of enterprises, etc.). Sociometric and sociological surveys are commonly used to obtain qualitative indicators.

Qualitative and quantitative indicators are substantiated by technical and economic indicators. They reflect the level of use of natural resources and labor, as well as provide a scientific basis for the location of industries and industries.

To assess the effectiveness of the system of work motivation at the macro and meso- and macroeconomic levels, we have developed a system of indicators that characterize the complex and systemic impact on the management object: economic indicators; organizational and administrative indicators; socio-psychological indicators; educational and cultural (intellectual) indicators; indicators of innovation activity.

The comprehensive scorecard captures the key dimensions of motivational support for work and allows to detail the real composition of the employee's needs, their hierarchy and the ability to influence and manage them in the context of overcoming problems and identifying ways to build a socially oriented innovative national economy.

\section{Conclusions.}

Our study suggests that the system of work motivation in the conditions of innovative development of the economy should be considered as a process of interaction of objective and subjective factors and the use of innovative methods of influence that encourage the creative activity of workers, considering them as active subjects of innovation changes. This approach allows to systematize methods and approaches to comprehensive assessment of the system of work motivation, which is based on the separation of organizational, economic, socio-psychological, intellectual and innovative subsystems of indicators. structure of employment, analyze their dynamics, determine the degree of interdependence of structural shifts within the labor market and the ability of existing systems EMI motivation to be the driving force behind the economic behavior of the employee, to induce him to effectively work, innovation to meet individual and social needs.

\section{References}

Adams, J. S. (1963), "Towards an understanding of inequity", The Journal of Abnormal and Social Psychology, vol. 67, no.5, pp. 422-436. doi: https://doi.org/10.1037/h0040968

Ageev, V. M. (1984), Ekonomicheskie interesy i stimuly pri sotsializme [Economic interests and incentives under socialism], Sovetskaya Rossiya, Moscow, Russia, 192 p.

Bakulina, O. S. (2015), "Staff motivation at agricultural enterprises under the conditions of implementing the European integration priorities”, Ph.D. Thesis, Economics and Enterprise Management (according to the Economic Activity), Zhytomyr National Agroecological University, Zhytomyr, Ukraine.

Bohynia, D. P. (2008), "Innovative work in the conditions of economy transformation", Bulletin of the Donbas State Machine-Building Academy, no. 2, pp. 40-43.

Herzberg, F. (1966), Work and the nature of man, World Publishing Co., Cleveland, USA, 203 p.

Hrishnova, O. A. (2004), Ekonomika pratsi ta sotsialno-trudovi vidnosyny [Labor economics and social and labor relations], Znannia, Kyiv, Ukraine, 535 p.

Kolot, A. M. (2008), "Innovative labour and intellectual capital in the system of factors of knowledge economy formation”, in: Lukianenko, D. H. (ed.) and Poruchnyk, A. M. (ed.) (2008), Hlobalna ekonomika stolittia: 
liudskyi vymir [The Global economy of the 21st century: human dimension], KNEU, Kyiv, Ukraine, pp. 93104, available at: https://r.kneu.edu.ua/bitstream/handle/2010/11431/93-104.pdf?sequence=1\&isAllowed $=\mathrm{y}$ (Accessed 25 January 2020).

Koval, L. A. (2002), "Socio-economic levers of activation of innovative labor at industrial enterprises", Ph.D. Thesis, Demography, labor economics, social economy and politics, Institute of Economics of the National Academy of Sciences of Ukraine, Kyiv, Ukraine.

Maslow, A. A (1943), “A theory of human motivation”, Psychological Review, vol. 50, no. 4, pp. 370-396. doi: https://doi.org/10.1037/h0054346

Mayo, E. (1946), The social problems of an industrial civilization, Graduate School of Business Administration, Harvard University, Boston, USA, 196 p.

McClelland, D. C. (1987), Human motivation, Cambridge University Press, New York, USA, 672 p.

McGregor, D. (1960), The human side of enterprise, McGraw-Hill, New York, USA, 246 p.

Semykina, M. V. and Koval, L. A. (2002), Innovatsiyna pratsya v konkurentnomu seredovishchi: zagalna metodologiya, motivatsiyni osnovi regulyuvannya [Innovative labour in a competitive environment, general methodology, motivational bases of regulation], KOD, Kirovohrad, Ukraine, 216 p.

Semykina, M. V. (ed.), Pasieka, S. R., Fedunets, A. D., Koval, L. A. and Zbarzhevetska, L. D. (2012), Innovatsiina pratsia: diahnostyka problem, vazheli aktyvizatsii [Innovative labour: Diagnostics of problems, levers of activation], MAKLAUT, Cherkasy, Ukraine, 320 p., available at: http://dspace.kntu.kr.ua/jspui/bitstream/123456789/5943/1/monohr.\%20Innovatsiyna\%20pratsya.pd (Accessed 25 January 2020).

Shershniova, Z. Ye. (ed.), Bahatskyi, V. M. and Hetmantseva, N. D. (2007), Antykryzove upravlinnia pidpryiemstvom [Anti-crisis management of the enterprise], KNEU, Kyiv, Ukraine, $680 \mathrm{p}$.

Taylor, F. W. (1947), Scientific management: comprising shop management, the principles of scientific management, testimony before the Special House Committee, Harper \& Brothers, New York, USA, 287 p.

Vroom, V. H. and Jago, A. G. (1988), The new leadership: Managing participation in organizations. PrenticeHall, Englewood Cliffs, USA, 244 p.

Цей твір ліцензовано на умовах Ліцензії Creative Commons «/з Зазначенням Авторства - Некомерційна 4.0 Міжнародна» (CC BY-NC 4.0).

This is an open access journal and all published articles are licensed under a Creative Commons "Attribution-NonCommercial 4.0 International" (CC BY-NC 4.0). 